\title{
L-securinine induces apoptosis in the human promyelocytic leukemia cell line HL-60 and influences the expression of genes involved in the PI3K/AKT/mTOR signaling pathway
}

\author{
SHUWEN HAN ${ }^{1}$, GANG ZHANG ${ }^{1}$, MAIDONG LI ${ }^{1}$, DONGYUN CHEN ${ }^{2}$, \\ YING WANG $^{3}$, WENCAI YE ${ }^{3}$ and ZHAONING JI ${ }^{2}$ \\ ${ }^{1}$ Department of Oncology, Wannan Medical College, Wuhu, Anhui; ${ }^{2}$ The Cancer Center, \\ Yijishan Hospital of Wannan Medical College, Wuhu, Anhui; ${ }^{3}$ Institute of Traditional Chinese \\ Medicine and Natural Products, Jinan University, Guangzhou, P.R. China
}

Received December 2, 2013; Accepted February 3, 2014

DOI: 10.3892/or.2014.3101

\begin{abstract}
The Securinega alkaloids are a class of natural products isolated from plants of the Euphorbiaceae family. L-securinine induces apoptosis in the human promyelocytic leukemia cell line HL-60 indicating its potential as an efficient natural antitumor drug with low toxicity. The aim of the present study was to investigate the apoptotic effects of L-securinine on HL-60 cells and to explore its potential underlying molecular mechanism(s) as an antitumor agent. HL-60 cells were cultured with L-securinine. The proliferation and changes in cell morphology were evaluated by Cell Counting Kit-8 (CCK-8) assay and electron microscopy, respectively. Induction of apoptosis and cell cycle progression were investigated by flow cytometry. The PI3K/AKT/mTOR pathway gene expression was measured by quantitative PCR (qPCR). L-securinine decreased the viability of HL-60 cells in a dose- and time-dependent manner, with $\mathrm{IC}_{50}$ values at 24 , 48 and $72 \mathrm{~h}$ post-treatment of $47.88,23.85$ and $18.87 \mu \mathrm{mol} / 1$, respectively. Numerous apoptotic bodies were observed in the HL-60 cells treated with $25 \mu \mathrm{mol} / 1 \mathrm{~L}$-securinine for $48 \mathrm{~h}$. L-securinine at $12.5,25$ and $50 \mu \mathrm{mol} / 1$ increased the rate of apoptosis in HL-60 cells, and G1/S phase progression was retarded. Furthermore, L-securinine induced downregulation of PI3K, AKT and mTOR gene expression and upregulation of PTEN gene expression in a dose-dependent manner. In conclusion, L-securinine induces apoptosis and inhibition of cell cycle progression in HL-60 cells by modulation of the PI3K/ AKT/mTOR pathway gene expression. These observations indicate the potential of L-securinine as an antitumor agent.
\end{abstract}

Correspondence to: Dr Zhaoning Ji, The Cancer Center, Yijishan Hospital of Wannan Medical College, 92 West Zheshan Road, Wuhu, Anhui 241001, P.R. China

E-mail: jzning@163.com

Key words: L-securinine, apoptosis, HL-60 cells

\section{Introduction}

Therapeutic approaches to human leukemia include irradiation, hyperthermia and chemotherapy. Overall survival rates of children currently range from 83 to $94 \%$ for acute lymphoblastic leukemia (ALL) (1) and from 60 to $65 \%$ for acute myeloid leukemia (AML) (2). The survival rates have improved markedly over time, largely due to conventional chemotherapy. However, the side-effects of cytotoxic chemotherapy are significant, and drug resistance in cancer remains a challenge when attempting to cure leukemia. Therefore, the development of effective antitumor drugs with high efficacy and low toxicity represents a focus of current research in this area.

Recently, great attention has been given to the identification of natural substances capable of inhibiting or retarding the progression of different stages of carcinogenesis. Antineoplastic drugs from natural sources capable of targeted specific cytotoxicity and induction of apoptosis in cancer cells with minimal side-effects are the best choice (3). The Securinega alkaloids are a class of natural products isolated from the plants of the Euphorbiaceae family. Securinine was initially isolated from Securinega suffruticosa by Russian scientists in 1956 (4). Its structure was determined by chemical and spectroscopic studies in 1963 (5) and was verified by X-ray crystallography in 1965 (6). There are two optical isomers, L-securinine and D-securinine, with the pharmacological activity of D-securinine being weaker (by $~ 10 \%$ ) than that of L-securinine (7). Securinine exhibits interesting biological activities. It has been reported to be a GABA receptor antagonist (8) and to exert aplastic anemia activity (9). Recent publications have reported that securinine exhibits antimalarial (10) and antibacterial (11) activities as well as apoptotic activity in human colon cancer SW480 cells (12). Thus, the pharmacology and clinical applications of securinine have recently attracted significant attention.

The phosphatidylinositol 3-kinase/AKT/mammalian target of rapamycin (PI3K/AKT/mTOR) signaling pathway plays an important role in cellular proliferation, development and death (13). This pathway, which was first identified in the 1990s (14), 


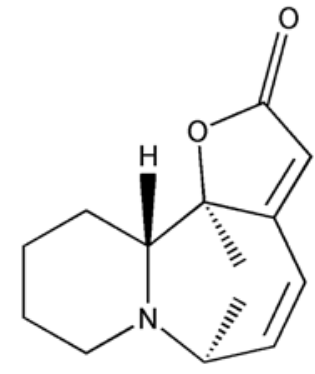

Figure 1. Structure of L-securinine.

is known to be activated during the early phase of the onset of lung cancer (15), thereby causing cell growth, proliferation, angiogenesis and synthesis of various proteins $(16,17)$. PI3K activates the serine/threonine kinase AKT, which, in turn, results in the phosphorylation and activation of the serine/threonine kinase mTOR through a cascade of regulators. The mTOR controls the PI3K/AKT/mTOR signaling pathway that promotes cell growth (18). The PI3K/AKT/mTOR pathway is dysregulated in many types of cancer, including AML (19).

Among the anticancer agents that interfere with PI3K/ AKT/mTOR signaling, inhibitors of mTOR have reached the furthest stage in clinical development and have demonstrated efficacy in renal cell carcinomas (20), neuroendocrine tumors (21) and breast cancer (22). The tumor suppressor, PTEN, is a phosphatase with a variety of substrate specificities that functions as a negative regulator of the PI3K/AKT/mTOR signaling pathway (23). Inactivation of PTEN increases ABCG2 expression and inhibition of PI3K/AKT/mTOR pathway components, thus representing an attractive therapeutic target in AML (24).

\section{Materials and methods}

Chemicals. The pure sample of L-securinine (Fig. 1) used in the present study was provided by the Institute of Traditional Chinese Medicine and Natural Products, Jinan University, China.

Cell culture. The human promyelocytic leukemia cell line HL-60, purchased from Nanjing KeyGen Biotech Co., Ltd. (Nanjing, China), was maintained in RPMI-1640 medium (Gibco, Carlsbad, CA, USA) supplemented with $10 \%$ heatinactivated fetal bovine serum (FBS; Sijiqing Biological Engineering Materials, Hangzhou, China; 120316), 100 IU/ml penicillin and $100 \mu \mathrm{g} / \mathrm{ml}$ streptomycin, in a humidified incubator (Sanyo XD-101; Sanyo, Osaka, Japan) with 5\% $\mathrm{CO}_{2}$ at $37^{\circ} \mathrm{C}$.

Analysis of cell viability. Exponentially growing HL-60 cells $\left(5.0 \times 10^{3}\right)$ were seeded into 96-well plates (3599; Corning Incorporated). After $24 \mathrm{~h}$, HL-60 cells were fed with RPMI-1640 medium containing 10\% FBS and treated (in triplicate) with L-securinine ( $200 \mu \mathrm{l} /$ well) at concentrations ranging from 0 to $400 \mu \mathrm{mol} / 1$. The plates were then cultured for 24,48 and $72 \mathrm{~h}$ at $37^{\circ} \mathrm{C}$. Cell viability was examined using the Cell Counting Kit-8 (CCK-8) (KGA317; Nanjing KeyGen Biotech) assays, which are based on the principle of
CCK-8 (water-soluble tetrazolium salt) cleavage to generate a formazan-class dye by mitochondrial succinate tetrazolium reductase in viable cells. Cell counting solution $(10 \mu \mathrm{l})$ was added to each well and incubated for $3 \mathrm{~h}$ prior to detection of formazan-class dyes by measuring the absorbance at $450 \mathrm{~nm}$ using a spectrophotometer (ELx800; Bio Tek Instruments, Winooski, VT, USA). The relative inhibition of cell proliferation (IR) was calculated according to the following formula: $\mathrm{IR}=\left(1\right.$ - average $\mathrm{A}_{450}$ of the experimental group/average $\mathrm{A}_{450}$ of the control group) $\mathrm{x} 100 \%$.

Electron microscopy. Induction of apoptosis in the L-securinine-treated HL-60 cells was evaluated by ultrastructural analysis of cell morphology as previously described. HL-60 cells were treated with or without L-securinine at a concentration of $25 \mu \mathrm{mol} / 1$ for $48 \mathrm{~h}$, washed three times with PBS, trypsinized and collected by centrifugation. Cells were then fixed for $2 \mathrm{~h}$ in $2.5 \%$ ice-cold glutaraldehyde for 30 min, then post-fixed with $1 \% \mathrm{OsO}_{4}$ in cacodylate buffer for $1 \mathrm{~h}$. Areas were chosen for ultra-thin sectioning and viewed with an electron microscope (JEM-1011 transmission electron microscope; JEOL, Peabody, MA, USA).

Analysis of cell apoptosis. Cells $\left(10^{6}\right)$ were treated with medium for $4 \mathrm{~h}$, followed by treatment with medium containing L-securinine at concentrations of $12.5,25$ and $50 \mu \mathrm{mol} / 1$ for $48 \mathrm{~h}$. After incubation, cells were harvested into 5 -ml centrifuge tubes and centrifuged at $300 \mathrm{x}$ g for $10 \mathrm{~min}$. Using cold PBS, the cells were washed three times, and a volume of $100 \mu \mathrm{l}$ binding buffer (Annexin V-FITC Apoptosis Detection Kit I (KGA105; Nanjing KeyGen Biotech) was added into the tube. Subsequently, Annexin V-FITC and propidium iodide (PI) solutions (both $1.25 \mu \mathrm{l}$ ) were added into the tube and incubated in the dark for $15 \mathrm{~min}$. Then, $1 \mathrm{X}$ binding buffer $(400 \mu \mathrm{l})$ was added to each tube and gently vortexed before flow cytometric analysis (FCM) (FACSCalibur; BD Biosciences, Franklin Lakes, NJ, USA). Approximately, 10,000 events were acquired and sorted accordingly into viable, early apoptotic, late apoptotic and necrotic cells $(25,26)$.

Cell cycle analysis. Cells $\left(10^{6}\right)$ were treated with medium for $4 \mathrm{~h}$, followed by treatment with medium containing L-securinine at concentrations of $12.5,25$ and $50 \mu \mathrm{mol} / 1$ for $48 \mathrm{~h}$. Cells were then collected and fixed in $70 \%$ ethanol at $4^{\circ} \mathrm{C}$ overnight. Subsequently, cells were treated with $1 \%$ RNase at $37^{\circ} \mathrm{C}$ and stained with PI solution (KGA511; Nanjing KeyGen Biotech) for $30 \mathrm{~min}$ at $4^{\circ} \mathrm{C}$. PI-stained nuclei were analyzed by flow cytometry (FACSCalibur; BD Biosciences). The ratios of the cells in the $\mathrm{G} 0 / \mathrm{G} 1, \mathrm{~S}$ and $\mathrm{G} 2 / \mathrm{M}$ phases were calculated (27).

Quantitative real-time RT-PCR. Quantitative real-time RT-PCR assays were performed on HL-60 cells treated with or without L-securinine in order to evaluate the expression of the following genes: PTEN, PI3K, AKT and mTOR. For each gene analyzed, total RNA from the cultured cells was isolated with TRIzol reagent (15596-026; Invitrogen, Carlsbad, CA, USA) according to the manufacturer's recommended protocol. A two-step reverse transcription PCR was performed. Firststrand cDNA was synthesized using $2 \mu \mathrm{g}$ of RNA with the First-Strand cDNA Synthesis kit (PC0002; Fermentas, Vilnius, 


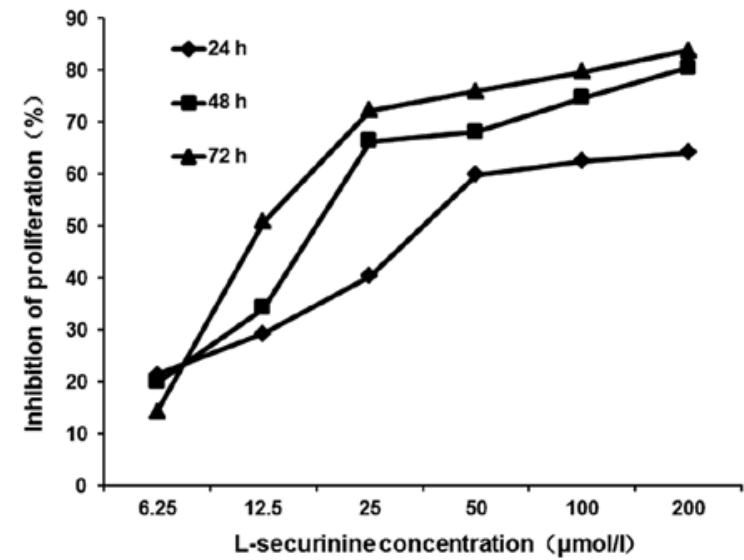

Figure 2. L-securinine caused dose- and time-dependent inhibition of HL-60 cell growth. The CCK-8 assay was used to determine the effects of L-securinine on the proliferation of HL-60 cells after being exposed to various concentrations of $\mathrm{L}$-securinine for 24,48 and $72 \mathrm{~h}$. Each value represents the mean $\pm \mathrm{SD}$ of three independent experiments. According to the relative cell proliferation inhibition rate $\left[(\mathrm{IR})=\left(1-\right.\right.$ average $\mathrm{A}_{490}$ of the experimental group/average $\mathrm{A}_{490}$ of the control group) $\mathrm{x} 100 \%$ ], L-securinine significantly inhibited the growth of HL-60 cells in a dose- and time-dependent manner. The $\mathrm{IC}_{50}$ values of L-securinine in HL-60 cells at 24,48 and $72 \mathrm{~h}$ post-treatment were $47.88,23.85,18.87 \mu \mathrm{mol} / 1$, respectively.

Lithuania) according to the manufacturer's protocol. To investigate the expression of genes at the mRNA level, the expression of CK8 and glyceraldehyde-3-phosphate dehydrogenase $(\mathrm{GAPDH})$ genes was quantified by RT-PCR, and GAPDH was used as an internal control. Quantitative real-time RT-PCR was conducted using $2 \mu \mathrm{l}$ of the primer mixture (forward and reverse; $10 \mu \mathrm{mol}$ ), added to $10 \mu \mathrm{l} \mathrm{SYBR-Green} \mathrm{and} \mathrm{then} \mathrm{diluted}$ with $7 \mu \mathrm{l}$ DEPC water. A final volume of $19 \mu \mathrm{l}$ was dispensed into each well, and $1 \mu \mathrm{l}$ of diluted cDNA was added. Each sample was tested in triplicate for each gene, and PCR reactions were performed using real-time fluorescence quantitative PCR (DA7600; Zhongshandaan, China). The thermal profile consisted of $95^{\circ} \mathrm{C}$ for $5 \mathrm{~min}$, followed by 40 cycles of $94^{\circ} \mathrm{C}$ for $15 \mathrm{sec}, 60^{\circ} \mathrm{C}$ for $20 \mathrm{sec}$, and $72^{\circ} \mathrm{C}$ for $40 \mathrm{sec}$. The experiment was repeated three times. The efficiency of cDNA synthesis for each sample was estimated by PCR with GAPDH-specific primers. The sequences of the primers used were as follows:
GAPDH forward, 5'-TGTTGCCATCAATGACCCCTT-3' and reverse, 5'-CTCCACGACGTACTCAGCG-3'; PTEN forward, 5'-CAAGATGATGTTTGAAACTATTCCAATG-3' and reverse, 5'-CCTTTAGCTGGCAGACCACAA-3'; PI3K forward, 5'-GGGGATGATTTACGGCAAGATA-3' and reverse, 5'-CACCACCTCAATAAGTCCCACA-3'; AKT1 forward, 5'-GCAGCACGTGTACGAGAAGA-3' and reverse, 5'-GGTGTCAGTCTCCGACGTG-3'; mTOR forward, 5'-ATT TGATCAGGTGTGCCAGT-3' and reverse, 5'-GCTTAGGA CATGGTTCATGG-3'.

Data analysis was performed using the Sequence Detector System software. The relative quantification was calculated by the $2^{-\Delta \Delta \mathrm{Ct}}$ method with GAPDH as the housekeeping gene and the control cells as the baseline, and the results are expressed as fold-changes.

Statistical analysis. The data are expressed as means \pm SD. Statistically significant differences between two groups were analyzed using the Student's t-test, and multiple comparisons were performed by one-way analysis of variance (ANOVA). All statistical analyses were performed using the SPSS 13.0 software. Statistical significance was accepted at a level of $\mathrm{P}<0.05$.

\section{Results}

L-securinine treatment inhibits HL-60 cell growth in vitro. The CCK-8 assay was used to determine the effects of L-securinine on the proliferation of HL-60 cells. L-securinine significantly inhibited the growth of HL-60 cells in a doseand time-dependent manner (Fig. 2), with $\mathrm{IC}_{50}$ values of 47.88 , 23.85 and $18.87 \mu \mathrm{mol} / 1$ at 24,48 and $72 \mathrm{~h}$ post-treatment, respectively.

L-securinine treatment induces apoptosis of HL-60 cells in vitro. The induction of apoptosis in HL-60 cells by L-securinine treatment was determined by electron microscopic analysis. The formation of apoptotic bodies, which are suggestive of active apoptosis, was observed in HL-60 cells treated with $25 \mu \mathrm{mol} / 1 \mathrm{~L}$-securinine for $48 \mathrm{~h}$, whereas none were observed in HL-60 cells in the control groups (Figs. 3 and 4).
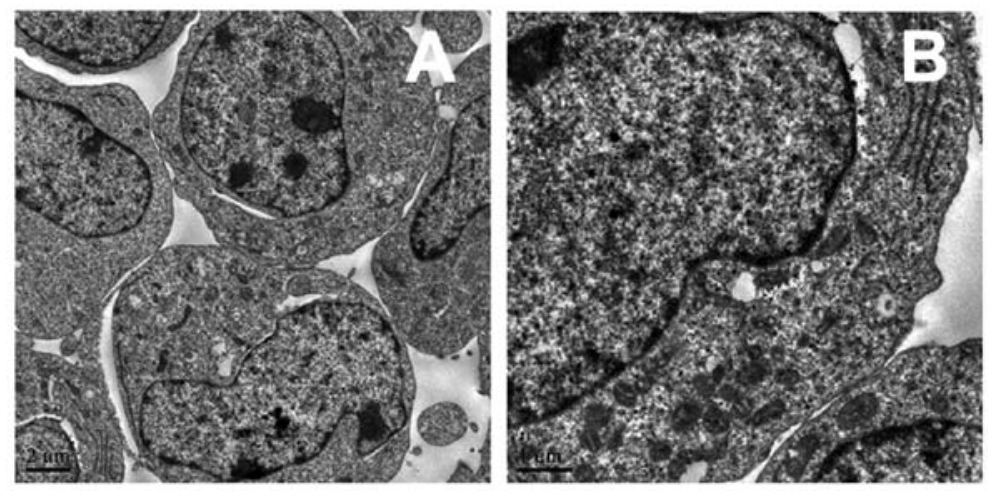

Figure 3. Control groups. To morphologically confirm the induction of apoptosis in L-securinine treated HL-60 cells, we performed ultrastructural analysis. HL-60 cells were treated without L-securinine for $48 \mathrm{~h}$, washed three times with PBS, trypsinized, and collected by centrifugation. The cells were then fixed for $2 \mathrm{~h}$ with $2.5 \%$ ice-cold glutaraldehyde for $30 \mathrm{~min}$, then postfixed with $1 \% \mathrm{OsO}_{4}$ in cacodylate buffer for $1 \mathrm{~h}$. Areas were chosen for ultra-thin sectioning and were viewed with an electron microscope. 


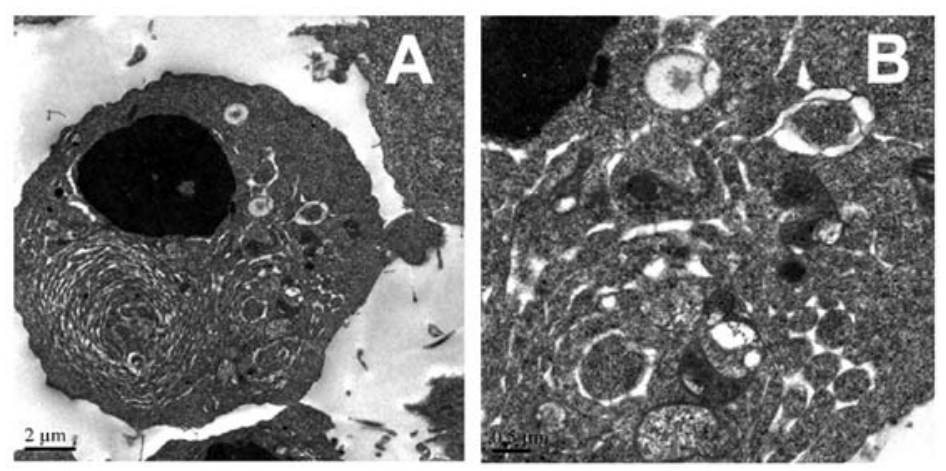

Figure 4. Cell morphology of HL-60 cells following treatment with $25 \mu \mathrm{mol} / \mathrm{L} \mathrm{L}$-securinine for $48 \mathrm{~h}$. To morphologically confirm the induction of apoptosis in L-securinine treated HL-60 cells, we performed ultrastructural analysis. HL-60 cells were treated with or without L-securinine at a concentration of $25 \mu$ mol/1 for $48 \mathrm{~h}$, washed three times with PBS, trypsinized, and collected by centrifugation. The cells were then fixed for $2 \mathrm{~h}$ with $2.5 \%$ ice-cold glutaraldehyde for $30 \mathrm{~min}$, and then postfixed with $1 \% \mathrm{OsO}_{4}$ in cacodylate buffer for $1 \mathrm{~h}$. Areas were chosen for ultra-thin sectioning and were viewed with an electron microscope.
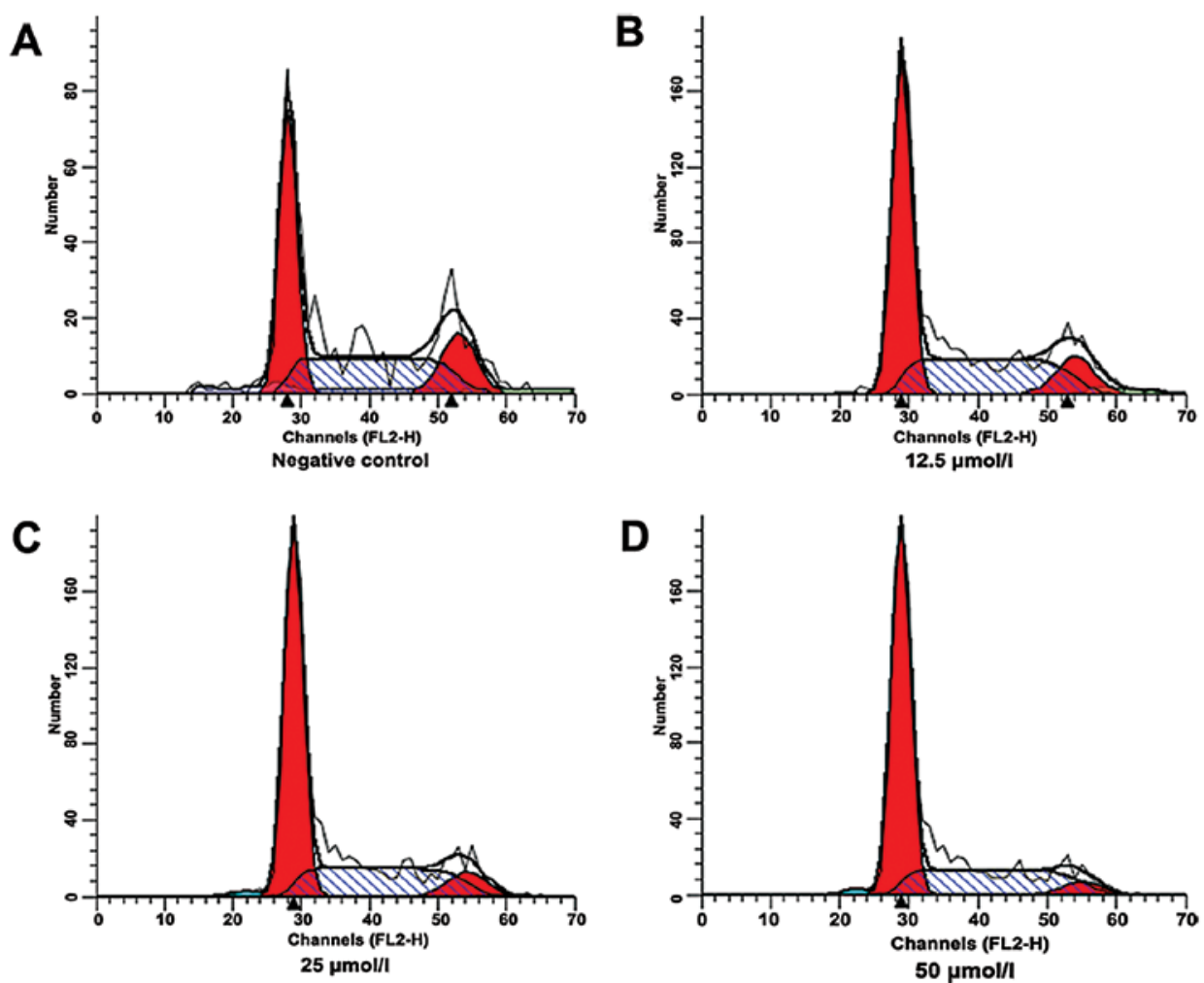

Figure 5. Flow cytometric analysis of cell cycle distribution of HL-60 cells following treatment with L-securinine. (A) Negative control HL-60 cells. Cells treated with (B) 12.5, (C) 25 and (D) $50 \mu \mathrm{mol} / 1 \mathrm{~L}$-securinine for $48 \mathrm{~h}$, respectively.

Table I. Cell cycle distribution of HL-60 cells treated with L-securinine at different concentrations for $48 \mathrm{~h}$ by flow cytometry.

\begin{tabular}{lccc}
$\begin{array}{l}\text { Concentration of } \\
\text { L-securinine }\end{array}$ & $\mathrm{G} 1(\%)^{\mathrm{a}}$ & $\mathrm{S}(\%)^{\mathrm{a}}$ & $\mathrm{G} 2(\%)$ \\
\hline $0(\mu \mathrm{mol} / \mathrm{l})$ & 42.13 & 40.54 & 17.33 \\
12.5 & 51.14 & 37.78 & 11.08 \\
25 & 59.82 & 32.55 & 7.63 \\
50 & 64.02 & 31.79 & 4.20 \\
\hline
\end{tabular}

${ }^{\mathrm{a}} \mathrm{P}<0.05\left(\chi^{2}\right.$ test for $\mathrm{RxC}$ table $)$.
L-securinine treatment inhibits $H L-60$ cell cycle phase progression in vitro. Cell cycle analysis of HL-60 cells following treatment with L-securinine $(0,12.5,25$ and $50 \mu \mathrm{mol} / \mathrm{l}$ ) for $48 \mathrm{~h}$ was performed using flow cytometric techniques. A dose-dependent increase in apoptosis was observed in the sub-G1 population of HL-60 cells treated with L-securinine (Fig. 5). Furthermore, the percentage of HL-60 cells in the G1 phase was observed to be 51.14, 59.82 and $64.02 \%$ following treatment with $12.5,25$ and $50 \mu \mathrm{mol} / 1$ L-securinine, respectively (Fig. 5; Table I).

L-securinine treatment induces apoptosis in HL-60 cells in vitro. Apoptosis rates in HL-60 cells treated with 

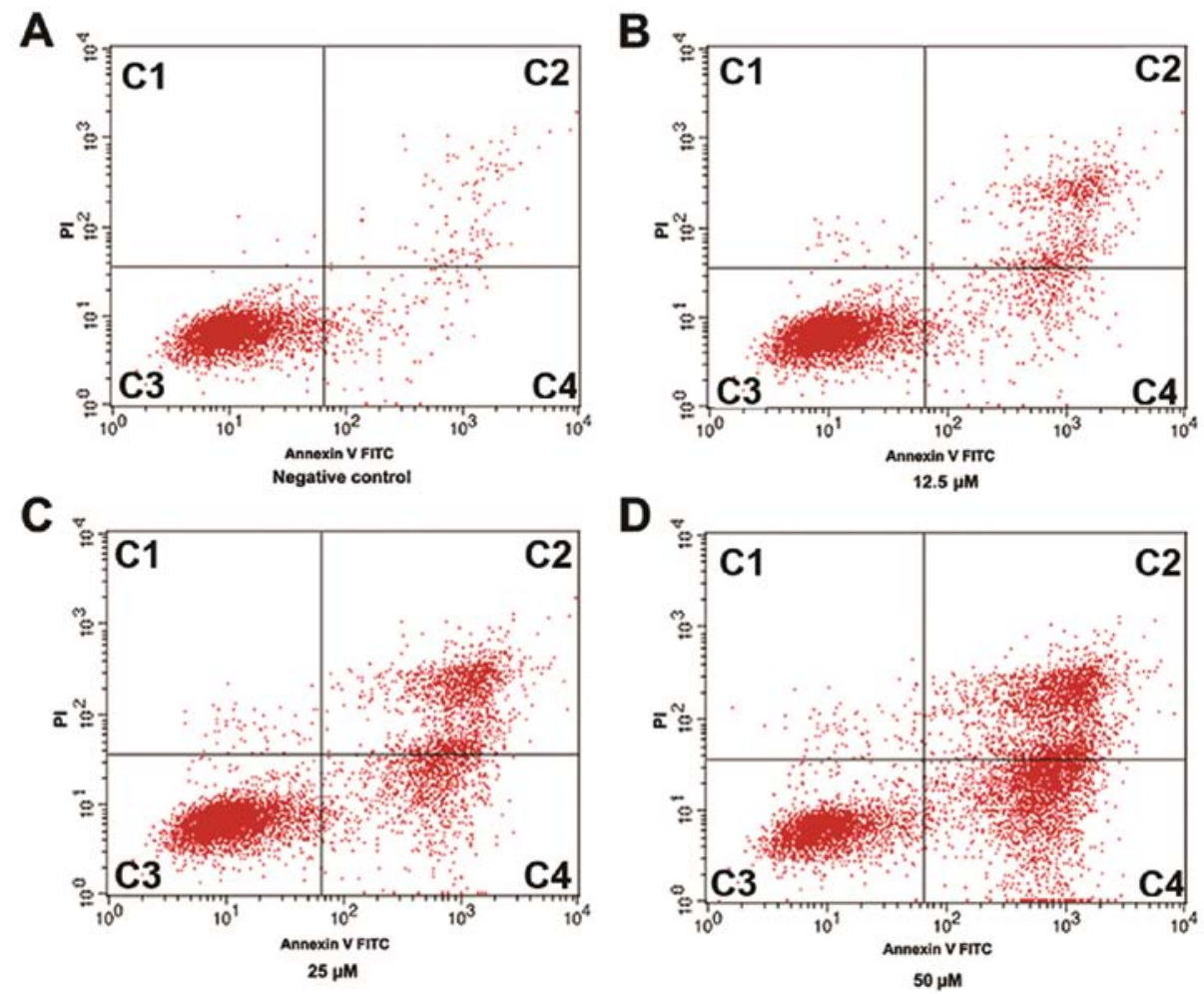

Figure 6. Flow cytometric analysis of apoptosis in HL-60 cells following treatment with L-securinine. Apoptotic cell rates using FACS scan following L-securinine treatment in HL-60 cells. (A) Negative control HL-60 cells. HL-60 cells treated with (B) 12.5, (C) 25.0 and (D) 50.0 $\mu$ M of L-securinine for $48 \mathrm{~h}$, respectively.

Table II. Comparison of HL-60 cell apoptosis induced by L-securinine at different concentrations at $48 \mathrm{~h}$ as assayed by Annexin V-FITC method.

\begin{tabular}{lcc}
\hline $\begin{array}{l}\text { Concentration of } \\
\text { L-securinine }\end{array}$ & Apoptosis $(\%)^{\mathrm{a}}$ & LL $(\%)^{\mathrm{a}}$ \\
\hline $0(\mu \mathrm{mol} / \mathrm{l})$ & 6.24 & 93.65 \\
12.5 & 20.42 & 79.11 \\
25 & 37.14 & 62.19 \\
50 & 66.36 & 32.72
\end{tabular}

${ }^{\mathrm{a}} \mathrm{P}<0.05$ ( $\chi^{2}$ test for $\mathrm{RxC}$ table $)$.

L-securinine were determined by flow cytometric analysis of FITC-Annexin V and PI staining. The percentages of cells in each quadrant in Fig. 6 are representative of: (C1) necrosis, (C2) late apoptosis, (C3) live cells and (C4) early apoptosis. A marked dose-dependent increase in both the early and late stages of apoptosis was obvious in the HL-60 cells after L-securinine treatment compared with the control group. The percentages of apoptotic cells treated with 12.5, 25.0 and $50.0 \mu \mathrm{mol} / 1 \mathrm{~L}$-securinine for $48 \mathrm{~h}$ were 20.42, 37.14 and $66.36 \%$, respectively (Fig. 6; Table II).

L-securinine treatment influences the PI3K/AKT/mTOR signaling pathway gene expression in HL-60 cells. The PI3K/ AKT/mTOR signaling pathway, which is vital in promoting cell growth and proliferation (13), is implicated in the mechanism underlying L-securinine-induced apoptosis in HL-60 cells. PI3K/AKT/mTOR pathway gene expression was measured by quantitative real-time RT-PCR. L-securinine treatment induced downregulation of PI3K, AKT and mTOR gene expression and upregulation of PTEN gene expression in HL-60 cells in a dose-dependent manner (Fig. 7; Table III).

\section{Discussion}

Identification of novel natural compounds that mediate cancer cell cytotoxicity with high specificity and low nonspecific toxicity is an important area in cancer research. In the present study, we showed that L-securinine inhibits HL-60 cell growth, induces apoptosis and enhances the expression of genes involved in the PI3K/AKT/mTOR signaling pathway in a dose-dependent manner. Our studies revealed that the $\mathrm{IC}_{50}$ values for L-securinine in HL-60 cells at 24,48 and $72 \mathrm{~h}$ post-treatment were 47.88, 23.85 and $18.87 \mu \mathrm{mol} / 1$, respectively. According to The US National Cancer Institute NCI Plant Screening Program, in vitro cytotoxicity activity of a crude extract is demonstrated by $\mathrm{IC}_{50}$ values of $<20 \mu \mathrm{g} / \mathrm{ml}$ (919 $\mu \mathrm{mol} / \mathrm{l}$ ) following incubation between 48 and $72 \mathrm{~h}$ (28). Thus, our data demonstrated that L-securinine exhibits in vitro cytotoxic activity in HL-60 cells.

Anti-neoplastic drugs act by interfering with cell proliferation or, in most cases, by inducing programmed cell death, known as apoptosis (29). In the present study, numerous apoptotic bodies were observed by electron microscopy in HL-60 cells following treatment with $25 \mu \mathrm{mol} / 1 \mathrm{~L}$-securinine for $48 \mathrm{~h}$. Furthermore, FCM analysis revealed that the rate of apoptosis in L-securinine-treated HL60 cells was increased 
Table III. qPCR analysis of PTEN, PI3K, Akt and mTOR mRNA in HL-60 cells treated with L-securinine at 6.25, 12.5 and $25.0 \mu \mathrm{mol} / \mathrm{l}$ for $48 \mathrm{~h}$.

Concentration of

L-securinine

mTOR/GAPDH

PI3K/GAPDH

AKT/GAPDH

PTEN/GAPDH

\begin{tabular}{|c|c|c|c|c|}
\hline $0(\mu \mathrm{mol} / \mathrm{l})$ & $1.00 \pm 0.03^{\mathrm{a}}$ & $1.00 \pm 0.03^{\mathrm{a}}$ & $1.00 \pm 0.02^{\mathrm{a}}$ & $1.00 \pm 0.02^{\mathrm{a}}$ \\
\hline 12.5 & $0.72 \pm 0.02^{\mathrm{b}}$ & $0.80 \pm 0.03^{b}$ & $0.72 \pm 0.02^{\mathrm{b}}$ & $2.14 \pm 0.04^{\mathrm{b}}$ \\
\hline 25 & $0.45 \pm 0.01^{\mathrm{c}}$ & $0.53 \pm 0.01^{\mathrm{c}}$ & $0.47 \pm 0.03^{\mathrm{c}}$ & $5.62 \pm 0.12^{\mathrm{c}}$ \\
\hline 50 & $0.12 \pm 0.02^{\mathrm{d}}$ & $0.25 \pm 0.02^{\mathrm{d}}$ & $0.26 \pm 0.01^{\mathrm{d}}$ & $10.24 \pm 0.43^{\mathrm{d}}$ \\
\hline
\end{tabular}

Between two different letters, $\mathrm{P}<0.05$; between the same letter, $\mathrm{P}>0.05$. (SNK test).

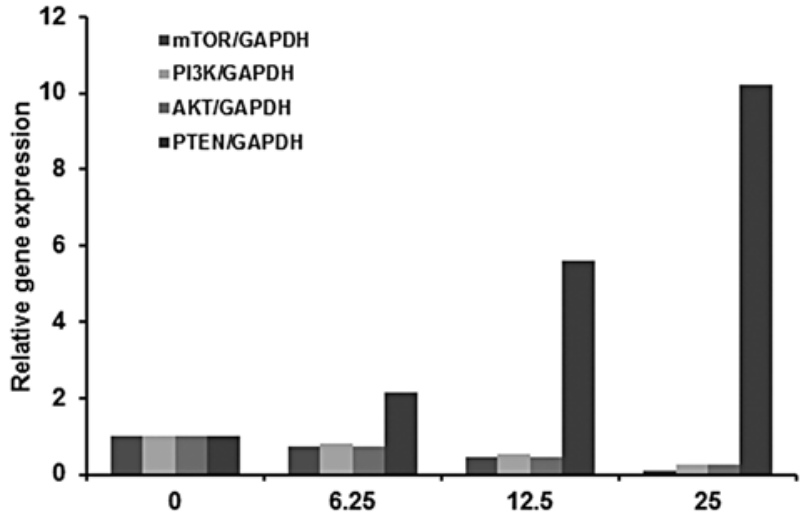

Figure 7. RT-qPCR analysis of genes in HL-60 cells treated with L-securinine at $6.25,12.5$ and $25 \mu \mathrm{mol} / 1$ for $48 \mathrm{~h}$.

in a dose-dependent manner over the range of $12.5,25$ and $50 \mu \mathrm{mol} / 1$ and that this effect correlated with an increase in the number of cells arrested in the G1 phase of the cell cycle. Apoptosis provides a number of clues with respect to effective anticancer therapy, and many anti-neoplastic agents exert their antitumor effects in cancer cells by inducing apoptosis. These data provide strong evidence that L-securinine has the potential to be developed as an antineoplastic agent for clinical use.

The present study also revealed that L-securinine influences the expression of genes involved in the PI3K/AKT/ mTOR signaling pathway, which promotes cell survival, proliferation and progression in cancer cells. Specifically PI3K, AKT and mTOR gene expression was downregulated in a dose-dependent manner in response to L-securinine treatment, while PTEN gene expression was upregulated. These observations indicate that targeting the PI3K/AKT/mTOR signaling pathway may lead to the development of novel therapeutic approaches for human cancers (30). Taken together, these data illustrate a new and imperative role for PI3K/AKT/mTOR signaling in the mechanism by which L-securinine induces apoptosis in HL-60 cells.

The aim of the present study was to investigate the potential of natural compounds, such as L-securinine, to exclusively target cancer cells. Our results demonstrated that L-securinine induces apoptosis and inhibition of cell cycle progression in HL-60 cells via a mechanism that involves modulation of PI3K/AKT/mTOR pathway gene expression. Although further studies are required to investigate the effects of L-securinine in vitro in normal cell lines, in vivo in animal models and finally, in humans through clinical trials, these observations indicate the potential of L-securinine for development as an antitumor agent.

\section{Acknowledgements}

The present study was supported by the fund of the National Natural Science Foundation of China (81241102). We would particularly like to thank the Institute of Traditional Chinese Medicine and Natural Products, Jinan University for providing the pure sample of L-securinine.

\section{References}

1. Pui CH: Recent research advances in childhood acute lymphoblastic leukemia. J Formos Med Assoc 109: 777-787, 2010.

2. Kaspers GJ and Creutzig U: Pediatric acute myeloid leukemia: international progress and future directions. Leukemia 19: 2025-2029, 2005.

3. Kim KC, Kim JS, Son JK and Kim IG: Enhanced induction of mitochondrial damage and apoptosis in human leukemia HL-60 cells by the Ganoderma lucidum and Duchesnea chrysantha extracts. Cancer Lett 246: 210-217, 2007.

4. Muraveva V and Bankovskii A: Chemical study of alkaloids of Securinega suffruticosa. Doklady Akad Nauk SSSR 110: 998-1000, 1956.

5. Saito S, Kotera K, Shigematsu N, Ide A, Sugimoto N, Horii Z, Hanaoka M, Yamawaki Y and Tamura Y: Structure of securinine. Tetrahedron 19: 2085-2099, 1963.

6. Imado S, Shiro M and Horii Z: The crystal structure of securinine hydrobromide dihydrate and the molecular structure of securinine. Chem Pharm Bull 13: 643-651, 1965.

7. Peng JZ: Securinine pharmacological and clinical progress. J Ningxia Med Coll 16: 2, 1994.

8. Beutler JA, Karbon EW, Brubaker AN, Malik R, Curtis DR and Enna SJ: Securinine alkaloids: a new class of GABA receptor antagonist. Brain Res 330: 135-140, 1985.

9. CL Y, LQ L and LS S: The treatment of aplastic anemia. Tianjin Med J 9: 662-665, 1981.

10. Weenen H, Nkunya MH, Bray DH, Mwasumbi LB, Kinabo LS, Kilimali VA and Wijnberg JB: Antimalarial compounds containing an $\alpha, \beta$-unsaturated carbonyl moiety from Tanzanian medicinal plants. Planta Med 56: 371-373, 1990.

11. Mensah JL, Lagarde I, Ceschin C, Michel G, Gleye J and Fouraste I: Antibacterial activity of the leaves of Phyllanthus discoideus. J Ethnopharmacol 28: 129-133, 1990.

12. Chen CR, Xia YH, Yao SY, Zhang Q, Wang Y and Ji ZN: Virosecurinine induces apoptosis by affecting Bcl-2 and Bax expression in human colon cancer SW480 cells. Pharmazie 67: 351-354, 2012. 
13. Carnero A, Blanco-Aparicio C, Renner O, Link W and Leal JF: The PTEN/PI3K/AKT signalling pathway in cancer, therapeutic implications. Curr Cancer Drug Targets 8: 187-198, 2008.

14. Burnett PE, Barrow RK, Cohen NA, Snyder SH and Sabatini DM: RAFT1 phosphorylation of the translational regulators p70 S6 kinase and 4E-BP1. Proc Natl Acad Sci USA 95: 1432-1437, 1998.

15. West KA, Linnoila IR, Belinsky SA, Harris CC and Dennis PA: Tobacco carcinogen-induced cellular transformation increases activation of the phosphatidylinositol 3'-kinase/Akt pathway in vitro and in vivo. Cancer Res 64: 446-451, 2004.

16. Janku F, Stewart DJ and Kurzrock R: Targeted therapy in nonsmall-cell lung cancer - is it becoming a reality? Nat Rev Clin Oncol 7: 401-414, 2010.

17. Reungwetwattana T, Weroha SJ and Molina JR: Oncogenic pathways, molecularly targeted therapies, and highlighted clinical trials in non-small-cell lung cancer (NSCLC). Clin Lung Cancer 13: 252-266, 2012.

18. Hay N and Sonenberg N: Upstream and downstream of mTOR. Genes Dev 18: 1926-1945, 2004.

19. Ozpolat B, Akar U, Steiner M, Zorrilla-Calancha I, Tirado-Gomez M, Colburn N, Danilenko M, Kornblau S and Berestein GL: Programmed cell death-4 tumor suppressor protein contributes to retinoic acid-induced terminal granulocytic differentiation of human myeloid leukemia cells. Mol Cancer Res 5: 95-108, 2007.

20. Hudes G, Carducci M, Tomczak P, Dutcher J, Figlin R, Kapoor A, Staroslawska E, Sosman J, McDermott D, Bodrogi I, Kovacevic Z, Lesovoy V, Schmidt-Wolf IG, Barbarash O, Gokmen E, O'Toole T, Lustgarten S, Moore L, Motzer RJ and Global AT: Temsirolimus, interferon alfa, or both for advanced renal-cell carcinoma. N Engl J Med 356: 2271-2281, 2007.

21. Yao JC, Shah MH, Ito T, Bohas CL, Wolin EM, Van Cutsem E, Hobday TJ, Okusaka T, Capdevila J, de Vries EG, Tomassetti P, Pavel ME, Hoosen S, Haas T, Lincy J, Lebwohl D and Oberg K; RAD001 in Advanced Neuroendocrine Tumors, Third Tria (RADIANT-3) Study Group: Everolimus for advanced pancreatic neuroendocrine tumors. N Engl J Med 364: 514-523, 2011.

22. Baselga J, Campone M, Piccart M, Burris HA III, Rugo HS Sahmoud T, Noguchi S, Gnant M, Pritchard KI, Lebrun F, Beck JT, Ito Y, Yardley D, Deleu I, Perez A, Bachelot T, Vittori L, Xu Z, Mukhopadhyay P, Lebwohl D and Hortobagyi GN: Everolimus in postmenopausal hormone-receptor-positive advanced breast cancer. N Engl J Med 366: 520-529, 2012.
23. Maiuri MC, Tasdemir E, Criollo A, Morselli E, Vicencio JM, Carnuccio $\mathrm{R}$ and Kroemer G: Control of autophagy by oncogenes and tumor suppressor genes. Cell Death Differ 16: 87-93, 2009.

24. Huang FF, Wu DS, Zhang L, Yu YH, Yuan XY, Li WJ, Chen XP, Zhao XL, Chen FP and Zeng H: Inactivation of PTEN increases ABCG2 expression and the side population through the PI3K/ Akt pathway in adult acute leukemia. Cancer Lett 336: 96-105, 2013.

25. Inayat-Hussain SH, Osman AB, Din LB and Taniguchi N: Altholactone, a novel styryl-lactone induces apoptosis via oxidative stress in human HL-60 leukemia cells. Toxicol Lett 131: 153-159, 2002.

26. Pelicano H, Feng L, Zhou Y, Carew JS, Hileman EO, Plunkett W, Keating MJ and Huang P: Inhibition of mitochondrial respiration: a novel strategy to enhance drug-induced apoptosis in human leukemia cells by a reactive oxygen species-mediated mechanism. J Biol Chem 278: 37832-37839, 2003.

27. Li L, Pan S, Zhou X, Meng X, Han X, Ren Y, Yang K and Guan Y: Reduction of in-stent restenosis risk on nickel-free stainless steel by regulating cell apoptosis and cell cycle. PLoS One 8: e62193, 2013.

28. Castello-Branco MVS, Tavares JF, Silva MS, Barbosa Filho JM, Anazetti MC, Frungillo L, Haun M, Melo Diniz MF and Melo PS: Xylodiol from Xylopia langsdorfiana induces apoptosis in HL60 cells. Revista Brasileira de Farmacognosia 21: 1035-1042, 2011.

29. Nahata A, Saxena A, Suri N, Saxena AK and Dixit VK: Sphaeranthus indicus induces apoptosis through mitochondrialdependent pathway in HL-60 cells and exerts cytotoxic potential on several human cancer cell lines. Integr Cancer Ther 12: 236-247, 2013.

30. Liu S, Wang XJ, Liu Y and Cui YF: PI3K/AKT/mTOR signaling is involved in (-)-epigallocatechin-3-gallate-induced apoptosis of human pancreatic carcinoma cells. Am J Chin Med 41: 629-642, 2013. 